\title{
The Implication of Naira Devaluation to the Nigeria's Economic Development
}

\author{
Udo Emmanuel Samuel ${ }^{1 *}$, Ben Etim Udo ${ }^{1}$ and Kingsley Idogen Imolemen ${ }^{2}$
}

${ }^{1}$ Department of Banking and Finance, Faculty of Business Administration, University of Nigeria, Enugu, Nigeria

${ }^{2}$ Department of Accountancy, Faculty of Business Administration, Veritas University, Abuja, Nigeria

\begin{abstract}
The fundamental intent of the study is to estimate the implication and affiliation flanked by economic development and Naira devaluation in Nigeria. The above intent shoot from assessing whether there are a significant affiliation and impact from devaluation to economic development proxied by (GDP). Which therefore forms the central argument of the study. The study by means of Classical Linear Regression Model (CLRM) adopts secondary data from 2000 to 2015. The Ordinary Least Square technique signifies the prime technique in relation to an array of other universal/ customary and analytical test. The R2 explains that $92 \%$ of the variation in GDP in the model study is explained by the principal regressors. Exchange and the inflation rate were sustained to have a positive and significant affiliation with GDP while, external debt, and public investment was negative and non-significant. The study established that devaluation is not peculiarly Nigerian. The results bare that devaluation does more harm than good within the Nigerian context since the needed prerequisite to ensure gains from devaluation are not present in the system.
\end{abstract}

Keywords: Devaluation; Exchange rate; Import; Export; Economic imbalance; Current account deficit

\section{Introduction}

Economic growth and development universally play host to three core fundamentals of short and long-run economic targets for the achievement of a stable and sustainable growth, employment, and a bare minimum inflation rate with a favourable trade point. The realizations of the above economic targets and profitability have propelled, nations over time to adopt monetary and fiscal policies to regulate the shift in the aggregate demand curve. Empirical research bare and recognized an economic world that in her earlier epoch witness economic depressions in 1910 and 1930s herein refer to as the "Great Economic Depression" which negatively impacted on the global economy with particular effect on domestic currencies. Which, therefore, propel nations to adopt devaluation as the last resort and as a key to economic lift. In the contemporary era, devaluation has been contained in line with the traditionalist argument as a macroeconomic policy tool for most developing economies of the world. The International Monetary Fund (IMF) and World Bank clinching to currency devaluation as a medium to domestic firms protection against external competition and increase net export boost [1]. Nations in conjunction with economic theories and in line with the traditionalist argument consensually cuddle devaluation as a fiscal policy and as a medium of domestic economic enhancement in the long-run by means of net export stimulation to economic diversification, increase domestic international competitiveness, trade balance expansion, employment generation and balance of payment alleviation so long as the Marshall-Lerner conditions are gratified. The Marshall-Lerner condition holds that; devaluation enhances expansion where the sum of price elasticity of demand for export and the price elasticity of demand for imports is greater than unity $(>1)$ [1]. The Nigerian economy over the decade has been recognized to be a monocultural and oil-driven. With oil funding 95 percent of foreign earnings, 80 percent to GDP, an above 90 percent of total export valued at $\$ 47.8$ billion consequently placing Nigeria as the $49^{\text {th }}$ largest exporter and import at $\$ 39.5$ billion placing Nigeria as the 53rd largest importer universally. Nigeria in the modern era is not immune from global economic and financial crisis. Nigeria, therefore, is currently trapped in the web of exchange rate volatility driving the adoption of devaluation as a feasible way out of the financial and economic quagmire [2].
Currency devaluation clinches to the fiscal policy which focal point on a calculated cutback in the value of the domestic currency to maximize gains in trade [1]. Cooper, as cited in Momodu and Akani [3] currency devaluation, is likewise reflected to be a shocking policy embraced by the government. Hence, most governments reject devaluation in line with their economic pattern. Devaluation occurs where there are trade and payment deficits. With Thailand, China, Mexico, Czech Republic devaluing strongly, willingly or unwillingly, due to deficits in trade exceeding $8 \%$ of GDP [3]. Nigeria in 1973 cuddles her first currency devaluation at $10 \%$ in response to US devaluation of the same year at foreign exchange reserves growth at $773.5 \%$ in 1974 . According to International Monetary Fund, report 2015 (IMF) nations can devalue their currency to correct "elementary disequilibrium" in trade and balance of payments. Todaro in 1982 augured that "devaluation is unhealthy for economic development since valued currency equally worsens trade and balance of payment. Momodu and Akani [3] instituted that, the monetarists economists argued the non-existence of devaluation effect on real variables in the long run with the view that exchange rate devaluation affects real trade balance only in the short run without any effect on real variables on the long run in relation to, Purchasing Power Parity (PPP) assumption, which states that increase in exchange rate in the short run leads to increase in output and balance of payments. While devaluation effect, in the long run, neutralize increase in output and a favourable balance of payment by way of the price increase. The arguments above are debatable in nature, which therefore forms the basics to further empirically investigate the implication and affiliation of currency devaluation to the development

*Corresponding author: Udo Emmanuel Samuel, Faculty of Business Administration, Department of Banking and Finance, University of Nigeria, Enugu campus, Enugu, Nigeria; Tel:+234-8033425686; E-mail: emmanuelkenrick@gmail.com

Received February 05, 2018; Accepted March 20, 2018; Published March 27 2018

Citation: Samuel UE, Udo BE, Imolemen KI (2018) The Implication of Naira Devaluation to the Nigeria's Economic Development. Bus Eco J 9: 343. doi: 10.4172/2151-6219.1000343

Copyright: (c) 2018 Samuel UE, et al. This is an open-access article distributed under the terms of the Creative Commons Attribution License, which permits unrestricted use, distribution, and reproduction in any medium, provided the original author and source are credited. 
of the Nigerian economy. The fundamental question and problem still remain is the Nigerian investment and business climate favourable to boost locally produce goods and magnetize foreign earnings in the face of devaluation?

\section{Objective of the Study}

The fundamental objectives of this study play host to the implication of naira devaluation to the development of the Nigerian economy.

\section{Review of Related Literature}

\section{Currency devaluation}

Momodu and Akani [3] affirmed currency devaluation to be an endogenous factor affecting economic performance generally, where the required factors to aid achieve its positive benefits are not available. Devaluation as a deliberate reduction in the value of the currency in a particular nation in relation to other currencies of nations partaking international trade within the framework of the fixed exchange rate to boost growth.

Okaro [4] currency devaluation is habitually triggered when there is a deficit in trade balance and balance of payment (BOP/BOT) with the 2016-2017 naira devaluation in Nigeria associated to shocks springing out from the declining oil price and external economic and financial shocks.

Currency devaluation cuddles acceptance in Nigeria during the Babangida led administration in 1986 designed to achieve a pragmatic exchange and economic growth. follows:

The three key traditional approaches to currency devaluation as

The elasticity approach,

The absorption approach, and

The monetary approach.

\section{Theoretical Framework}

The elasticity approach; Embraces devaluation as an instrument upon which a country's balance of trade can be improved upon on. They clearly state that the effect of devaluation solely dependent on the elasticity of exports and imports. The elasticity approach embraces two key models the Bickerdike-Robinson-Metzler (BRM) model and Marshall-Lerner (ML) condition. With both models studying the responsiveness of demand for imports and exports when devaluation is adopted in an economy. Bickerdike-Robinson-Metzler (BRM) model substantiate imports and exports reaction in relation to changes in price caused by the consciousness of devaluation.

The BRM models Assumptions; embraces only two countries, two commodities, initial market equilibrium, and the presence of free trade in the economy. According to Le Khak, cited as the model can be expressed as:

$$
\frac{d B}{d E}=\left(P_{X} X^{S}\left|(1+\varepsilon) \eta^{*} /\left(\varepsilon+\eta^{*}\right)\right|\right)-\left(\operatorname{PmMd} \mid(1+\eta) \varepsilon^{*} /\left(\varepsilon^{*}+\eta \mid\right)\right.
$$

\section{Where}

$\mathrm{dB}=$ derivative of normal exchange rate,

$\mathrm{Px}=$ export price,

$\mathrm{Pm}=$ import price,
Xs and $\mathrm{Md}=$ domestic supply and demand for export and import,

$\varepsilon$ and $\eta=$ absolute values of elasticity of domestic demand for export and import,

$\varepsilon^{*}$ and $\eta^{*}=$ foreign price elasticity of export and import demand.

The model established that exchange rate changes affect trade balance depending on the values of price elasticity of domestic supply and demand.

\section{If $|\varepsilon|>\eta \mid$}

When absolute value price elasticity of export supply is greater than that of import demand, it improves the trade and balance of payment after the adoption of devaluation and the vice versa. The hypothesis that devaluation improves trade balance position is also rooted in the BRM condition, known as the Marshall-Lerner condition states that; for nations to benefit from the positive effect of devaluation, the absolute values of the sum of demand elasticities for exports and imports must exceed unity (greater than 1) [5].

The absorption approach; established that without elasticity, trade balance can be improved if and only if there is a geometric increase in (GDP) than domestic spending. The elasticity approach alone is insufficient to drive a stable and favourable economy after devaluation. Johnson in 1967 and Miles in 1979 popularized the absorption analysis to devaluation which states that devaluation causes the terms of trade to deteriorate at the short run, and change expenditure from foreign goods to domestic goods thereby improving the trade balance [6] Kemal and Qadir as cited in Teru and Mohammed [6] expressed that, if the elasticity of demand for both import and export is greater than an elasticity of supply, then devaluation absolutely improves trade balance position positively.

Lencho [7] examine the absorption approach with key assumption that total domestic output $(\mathrm{Y})$ is equal to total spending, where total spending play host to four macroeconomic variables: consumption (C), investment (I), government expenditure $(\mathrm{G})$ and net export $(\mathrm{X}-\mathrm{M})$.

The four macroeconomic variables can be expressed as: $\mathrm{Y}=\mathrm{C}+\mathrm{I}+\mathrm{G}+(\mathrm{X}-\mathrm{M})$

The absorption approach embraces three economic aggregates $\mathrm{C}$ I and G.

\section{$\mathrm{A}=\mathrm{C}+\mathrm{I}+\mathrm{G}$}

$\mathrm{B}=$ net export $(\mathrm{X}-\mathrm{M})$.

The total domestic output is the sum of absorption and net exports (X-M) which is rewritten by substituting $\mathrm{A}$ and $\mathrm{B}$ into the former formula $\mathrm{Y}=\mathrm{A}+\mathrm{B}$.

To get the balance of trade (net export) is deduced $\mathrm{A}$ from $\mathrm{Y}$ the formula for the trade balance can be written as follows: $\mathrm{B}=\mathrm{Y}-\mathrm{A}$

When national output $(\mathrm{Y})$ is greater than domestic absorption (A), in the above equation, there is positive trade balance with a trade surplus. In contrary, when trade balance is negative, it indicates that the economy is spending beyond its ability to produce and trade deficit experienced [7].

The monetary approach; The argument emanating from monetary approach states that balance of payment is not real phenomenon rather it is a monetary phenomenon for that reason disequilibrium in the trade balance is caused by disequilibrium in the money market state that the main arguments of monetary approach as; 
"The balance of payments is a monetary phenomenon and thus requires analysis embracing tools of monetary theory and not barter" or " real trade theory, Second, money as stock, real theory traditionally deals with flows, adequate balance of- payments theory ought to integrate stocks and flows; Third, money stock can be changed in two alternative ways, via domestic credit creation or destruction and through international reserve flows, the policy choice being important for balance-of-payments analysis".

According to Lencho [7] monetary approach embraces three different assumptions which include:

a) Stable money demand function in the economy,

b) Vertical aggregate supply schedule and

c) Purchasing power parity.

\section{Determinants of devaluation (Naira) in Nigeria}

Devaluation universally is an end product of the decline in domestic currency in relation to major currencies of the world with its impact on the domestic economy depending on factors like:

i. Competitive Advantage of the economy

ii. Business cycle of the nation in relation to trading partners.

iii. The elasticity of demand for exports and imports

iv. Capital Flight

v. Inflation.

\section{Economic Growth and Development}

Economic growth and development are measured as an increase in the market value of the goods and services produced within a given economy and income per capita GNI. Conventionally it's measured as percent increase in real gross national product a given economy. Economic development embraces economic growth measured as changes in output distribution and economic and financial structure along with technological advancement within the country. Nigeria between 1960 and 1970, recorded GDP rate at 3.1 percent annual growth propel via the agricultural sector, from 1970 to 1980 Nigeria embraces oil boom, with a remarkable increase in GDP rate at 6.3 percent annual growth. In the early 1980s, Nigeria witness decrease in growth. Therefore, driving the adoption of 1986, structural adjustment and economic reform, to boost the near collapse economy with GDP growth rate at 4 percent. The GDP growth rate in Nigeria from 2013 to 2015 averaged at 1.32 percent, with the highest growth rate achieved in the third quarter of 2015 at 9.19 percent. The services sector accounted for 50 percent of the GDP while the fastest segment is information and communication. The agricultural sector accounts for 26 percent and oil sector accounts for 11 percent. The effect of undervaluation on growth appears to be large and highly significant, also, stronger for developing countries.

Exchange Rate Regime in Nigeria: Nigeria from 1959-1973 adopted British pound as an official exchange to Naira. The economy in 1971 was in devaluation dilemma either to devalue Naira or not. The Naira was not devalued during the American dollar devaluation process which results in dollar appreciation, the exchange rate at $\$ 2.80$ $\$ 3.80$ to the naira pound.

In 1973 Nigeria devalued at the same rate with the US exchange rate at $\$ 1.52$. In 1986 the exchange rate policy in Nigeria was transformed giving birth to the introduction of the structural adjustment program to address the structural imbalance in the economy [6].

In 1994, exchange rate was fixed at $\$ 22$ to a US dollar which implies a shift from the flexible regime of 1986 to fixed regime of 1994 with the foreign exchange market liberalized in 1995 paving way for the introduction of autonomous foreign exchange market (AFEM) for sale and purchase of foreign exchange dedicated by the government [6]. On October 25, 1999, the Inter-Bank Foreign Exchange Market (IFEM) was introduced with it operation experiencing similar problems and setbacks as that of AFEM. The CBN thus, re-introduced the Dutch Auction System (DAS) to replace the IFEM [6].

The implication of currency devaluation on the Nigerian economy: Currency devaluating totally is an end product of monetary decision to improve the nations near collapse economy. A devaluation is an attractive option for nations in a recession like Nigeria. Devaluation with its positive results also embraces negative consequences as such making imports more expensive, domestic industries are protected thereby making them become less efficient and effective without the pressure of competition. Business parameters in Nigeria are adversely affected by the increase in the rate of inflation, thus reducing the purchasing power of the populace along high unemployment rate. The 2016 cum first and second quarter of 2017 devaluation, according to CBN was to cut down negative speculations in the foreign exchange (forex) market and move the mid-point of the official window of the (forex) market by 100 basis points from 12 percent to 13 percent, to tightened monetary policy framework and allow a degree of flexibility in exchange rate, curtail speculative activities and foreign reserves depletion which, as at October, stood at N 37.1trillion.

\section{Criticisms against devaluation}

Over time lots of implication has been established and put forward to why devaluation is not desirable in Nigeria. Some of the reasons will be scrutinized.

The expensive nature of import basically raw materials and finished goods. This is more critical since Nigeria is an import-dependent country with key raw materials and consumable goods not manufacture in Nigeria. Increase Monetary Policy Rate (MPR) taking its toils on the real sector with the cost of investable funds increasing with a direct consequence on development becoming counterproductive. Hence, there is an indirect correlation between increased in interest rate and job creation [2].

\section{Empirical Framework}

Momodu and Akani [3] scrutinized the impact of currency devaluation on economic growth in Nigeria. Employing Johansen Co-integration technique with multivariate estimations. Result shows that there is at least one co-integrating vector affiliation flanked by growth and the independent variables. This therefore implies that there is a long run affiliation the variables. The autoregressive distributed lags (ARDL) approach was adopted for error correction mechanism (ECM). (ARDL) and (ECM) result signposts short-term changes in growth sufficiently explained by devaluation and other factors in the model. The study explains that devaluation in the short run leads to output increase, improve balance of payments. In the long run the monetary consequences of devaluation ensures that the increase in output and improvement in the balance of payment is neutralized by the rise in prices. Devaluation increases domestic goods affordability at the international market with interest and exchange rates significantly related. Increase in export rate increases production and investment 
level which automatically increase exchange rate. Soukiazis et al. [8] studied the effect of external and internal imbalances and the role of relative prices on economic growth rate in Portugal. Result shows that devaluation is a stimulus to growth. Examined devaluation of Nigerian Naira, Bane or Panacea, the study revealed that macroeconomic policy is the best alternative to address national issue. Findings revealed that devaluation does more harm than good as far as Nigeria is concerned. They established that devaluation should not be seen as a last resort each time there is global financial problem. Walter [9] examined the effect of the naira devaluation with recommendation its effect will be milder if major import are produced locally. Adekoya and Fagbohun [2] examined the impact of currency devaluation on manufacturing output growth in Nigeria between 1980 and 2014, employing Augmented Dickey-Fuller for stationarity test, Engel-Granger co-integration for long-run relationship, ordinary least square for long-run estimate and Granger causality test for causal relationships. The result revealed that all the variables are stationary at I (1) with a long-run relationship. It further showed that all the variables except import exert positive effect on manufacturing output growth.

\section{Methodology}

The study embraced the ex-post facto research design. With data from secondary nature by annualized time series from the CBN Statistical Bulletin 1999-2016 [10-13]. A combination of descriptive statistics, regression and Augmented Dickey-Fuller (ADF) test used for unit root test was adopted with an array of analytical tests conducted on the regression model to ensure that the key assumptions underlying the Classical Linear Regression Model (CLRM) were not violated.

\section{Model specification}

The equation for multiple linear regressions is given as follows:

$$
\mathrm{Y}=\mathrm{b}_{0}+\mathrm{b}_{1} \mathrm{X}_{1}+\mathrm{b}_{2} \mathrm{X}_{2}+\mathrm{b}_{\mathrm{n}} \mathrm{X}_{\mathrm{n}}
$$

Where

$\mathrm{Y}=$ dependent variable,

$\mathrm{b}_{0}=$ Intercept term,

$\mathrm{b}_{1}, \mathrm{~b}_{2}---\mathrm{b}_{\mathrm{n}}=$ Regression coefficients to be determined,

$\mathrm{X}_{1}, \mathrm{X}_{2}---\mathrm{X}_{\mathrm{n}}=$ set of explanatory variables.

To arrest the impact of devaluation on economic growth in Nigeria, the essential variables are tailored in on the LRM and log-transformed to ensure linearity and it appears thus:

LOGRGDP $_{t}=\beta_{0}+\beta_{1}$ LOGEXCR $_{t}+\beta_{2}$ LOGPDI $_{t}+\beta_{3}$ LOGINFR $_{t}+\beta_{4}$ LOG $\operatorname{EXDET}_{t}+u_{t}$

Where

RGDP=Real Gross Domestic Product,

EXDET $=$ External debts

PDI=Private Domestic Investments,

INFR-Inflation rate,

EXCR=Foreign exchange rate,

$\beta_{1}, \beta_{2}$, are coefficients of the parameter estimates or the slopes,

$\beta_{0}$, Intercept of the regression equation, $t$ Time Series.

\section{Presentation and Analysis of Data}

\section{Author's Extract from the full result}

Table 1 above shows aggregative averages like the mean, median as well as measures of spread and variation like standard deviation. The skewness measures of the degree of symmetry and kurtosis the degree of peakedness of the observation. The results on skewness and kurtosis submit a departure from normality. Is not strong enough to discredit the goodness of the dataset for the analyses in view.

To further evaluate the analytical affiliation of the variables under study, a scatter plot with fitted regression lines is presented in Figure 1.

According to the slope of the regression line, a positive linear relationship is inferred between GDP, EXCR, EXDET, INFR, and PDI showed a negative linear relationship with RGDP (Figure 1).

\section{Tests for unit root}

To ensure that the dataset is stationary, the variables were subjected to a unit root test following the Augmented Dickey Fueler Statistics and the result is presented in Table 2 (Figure 2).

Table 2 reports the test for stationarity properties of the series following the Augmented Dickey Fueler statistics. All the variables were found to be stationary at order 1 . At the first difference as reported, the

\begin{tabular}{|l|c|c|c|c|c|c|}
\hline Variable & Mean & Median & Skewness & Kurtosis & $\begin{array}{c}\text { Standard } \\
\text { Deviation }\end{array}$ & $\begin{array}{c}\text { No. of } \\
\text { Obs. }\end{array}$ \\
\hline LOGRGDP & 17.02 & 16.92 & 0.06 & 1.52 & 0.95 & 16 \\
\hline LOGEXTDET & 7.27 & 7.32 & -0.05 & 1.52 & 0.86 & 16 \\
\hline LOGEXCHR & 4.92 & 4.88 & 0.3 & 2.69 & 0.16 & 16 \\
\hline INFD & 16.9 & 14.50 & 2.76 & 10.57 & 16.05 & 16 \\
\hline PDI & 17.28 & 16.41 & 1.09 & 3.33 & 2.43 & 16 \\
\hline
\end{tabular}

Table 1: Description of the characteristics of the variables under study.

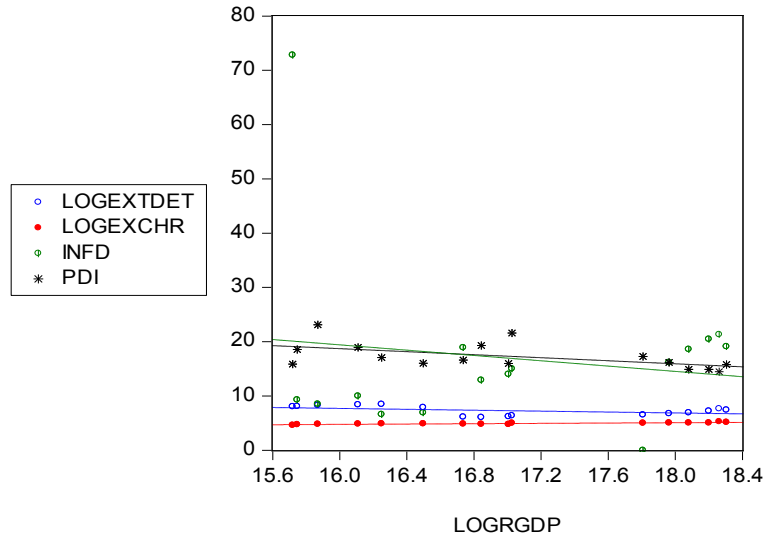

Source: Author's computation

Figure 1: A scatter plot of the economic growth and currency devaluation in Nigeria.

\begin{tabular}{|c|c|c|c|c|c|c|}
\hline \multirow[t]{2}{*}{ S/No } & \multirow[t]{2}{*}{ Variable } & \multirow{2}{*}{$\begin{array}{l}\text { ADF } \\
\text { Stat }\end{array}$} & \multicolumn{3}{|c|}{ Critical Values } & \multirow{2}{*}{$\begin{array}{c}\text { Order of } \\
\text { Integration @ 5\% }\end{array}$} \\
\hline & & & $1 \%$ & $5 \%$ & $10 \%$ & \\
\hline 1 & LOGRGDP & -4.03 & $-4.00^{* *}$ & $-3.09^{* *}$ & $-2.9^{\star *}$ & $\mathrm{I}(1)$ \\
\hline 2 & INFD & -9.96 & $-2.74^{* *}$ & $-1.96^{* *}$ & $-1.60^{* *}$ & $\mathrm{I}(1)$ \\
\hline 3 & LOGEXTDET & -2.43 & $-2.74^{\star *}$ & $-1.96^{* *}$ & $-1.60^{* *}$ & $\mathrm{I}(1)$ \\
\hline 4 & LOGEXCHR & -2.69 & $-2.47^{\star \star}$ & $-1.96^{* *}$ & $-1.60^{* *}$ & $\mathrm{I}(1)$ \\
\hline 5 & PDI & -4.99 & $-4.80^{* *}$ & $-3.79^{* *}$ & $-3.34^{* *}$ & $\mathrm{I}(1)$ \\
\hline
\end{tabular}

Table 2: Summary of ADF unit root tests. 
$\mathrm{ADF}$ statistics for the respective variables were more negative than the critical values at $5 \%$ level of significance. The reported $p$-values are all less than 0.05 for which cause, the null hypothesis of the presence of unit root in all the variables is convincingly rejected. This test essentially assures that the regression result would not be spurious.

\section{Estimation of regression model}

The result as contained in the model below follows the form specified in equation II. The model has all the coefficients of the parameter estimates duly fitted. The standard errors and the $t$-statistics for the parameter estimates are correspondingly shown.

LOGRGDP=-0.368LOGEXTDET+4.237LOGEXCHR+0.0015IN FD-0.088PDI

$\begin{array}{lllll}\mathrm{SE} & = & (0.09) & (0.54) & (0.00) \\ \mathrm{T} & = & {[-4.06]} & {[7.73]} & {[0.27]} \\ \text { Expectation } & = & (-) & (+) & (+)\end{array}$

It is essential however to discuss the diagnostic tests contained in Table 3 before analysing the significance of the Regression estimates. This is to ensure that there is no violation of the assumptions of the regression model as any of such assumptions casts doubts on the validity and reliability of the regression model.

From Table 3, it can be established that the model has the goodness of fit as the R2 of $92 \%$ suggests. This shows that $92 \%$ of the variation in the dependent variable is accounted for by the independent variables with an unexplained variation of about $8 \%$. The F-statistics of 35.9 and the corresponding probability value of 0.000 , indicates that the overall regression is statistically significant and can be used for meaningful analyses. The Durbin Watson Statistics of 1.3, creates a suspicion of the possible existence a first-order positive autocorrelation for which cause a higher order serial correlation test was conducted. The Breusch Godfrey Lagrange Multiplier Serial Correlation Test was used and the result of the F-stat with a p-value of 0.298 rules out the existence of autocorrelation thereby overriding the result posted by the DW Stat (with its inherent limitation).

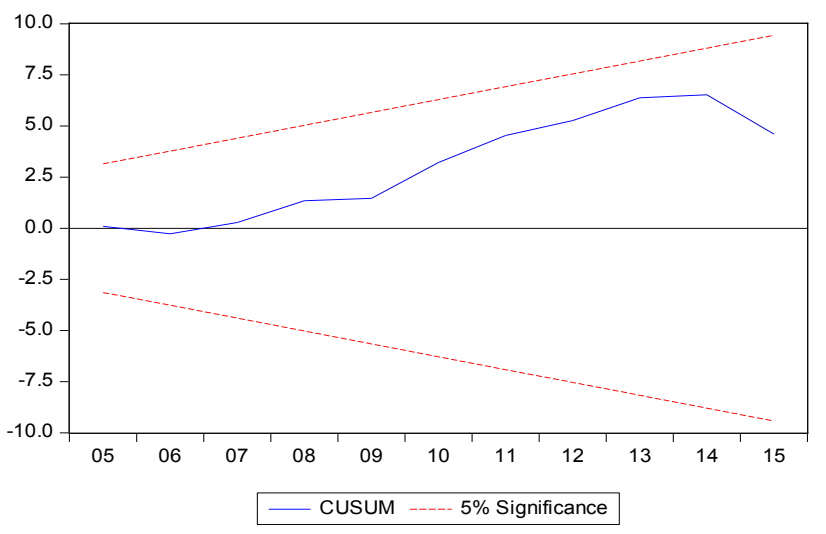

Source: Author's computation

Figure 2: Cumulative sum of squares stability test (RECURSIVE ESTIMATES ONLY).

\begin{tabular}{|c|c|c|c|c|c|}
\hline $\mathbf{R}^{\mathbf{2}}$ & $\mathbf{F}-$ Stat & DW & BG-F & $\mathbf{X}^{\mathbf{2}}$ (HET) & RESET-F \\
\hline 0.92 & 35.9 & 1.3 & 0.298 & 0.85 & 0.08 \\
\hline
\end{tabular}

Table 3: Diagnostics tests for the regression model.
In addition, a test for heteroskedasticity was carried out on the model to ensure that the assumption of homoskedasticity was not violated. From the result obtained, the $\mathrm{x} 2$ and F-stat all indicate that the model is homoscedastic. The regression error specification test as reported clearly shows that the model does not have an inclusion of any irrelevant variable neither does it have an omission of a relevant variable.

More so, Figure 2 below contains the cumulative sum of squares graph following the recursive estimates. This is a measure of the stability of the model. Evidently, the model is BLUE (Best Linear Unbiased Estimator) and lies intact between the lower and the upper bounds. This clearly points to the stability of the model.

From the result shown in equation III, the explanatory variables show a positive and significant relationship with the Real Gross Domestic Product.

\section{Summary, Recommendation and Conclusion}

This investigation analysis the implication and affiliation of devaluation with emphasis on Nigeria economic development. The fundamental intent is to evaluate the impact to development in Nigeria. The OLS Regression technique signifies the prime technique of estimation pooled with an array of other universal/customary and diagnostic tests. Economic growth proxide by (GDP) shows a positive affiliation with the exchange rate and inflation while, public debt and external debt negative affiliation. The R2 explained $92 \%$ of the variation in GDP in the model by the explanatory variables. The positive affiliation embraces a theoretical viewpoint that devaluation boosts economic growth in developed and developing economies. By implication, it is hard to consider or embrace devaluation in Nigeria since its adoption and implementation has always left the economic and investment climate us worse than before since the needed requirements to ensure it impactful benefits are not adequately provided in Nigeria. The argument of this research paper is that rather than Nigeria embracing devaluation as last resort in the event of economic and financial imbalances, government at all levels ought to review other possible solution to improve the economic and financial position of the nation. There is then a robust recommendation and activism for all-round economic diversification, real sector reformation, and periodic fiscal and monetary policies review in relation to the changing economic and financial climate in Nigeria.

\section{References}

1. Aiya F (2014) People's Perception of the Impact of Currency Devaluation on the Performance of Poverty Alleviation Programmes in Nigeria. Developing Country Studies IISTE 4: 7-16.

2. Adekoya OM, Fagbohun A (2016) Currency Devaluation and Manufacturing Output Growth in Nigeria. Journal of Economics and Sustainable Development 6: 207-218.

3. Momodu AA, Akani FN (2016) Impact of Currency Devaluation on Economic Growth of Nigeria. International Journal of Arts and Humanities 5: 151-163.

4. Okaro CS (2017) Currency Devaluation and Nigerian Economic Growth (20002015). Journal of Social Development.

5. Ogundipe A, Ojeaga P, Ogundipe O (2013) Estimating the Long Run Effects of Exchange Rate Devaluation on the Trade Balance of Nigeria. European Scientific Journal.

6. Teru P, Mohammed AMU (2017) Naira devaluation: Impact and implication on the Nigerian economy (1970-2014). International Journal of Commerce and Management Research 3: 168-169.

7. Lencho BD (2013) The Effect of Exchange Rate Movement on Trade Balance in Ethiopia. Tokyo University. 
Citation: Samuel UE, Udo BE, Imolemen KI (2018) The Implication of Naira Devaluation to the Nigeria's Economic Development. Bus Eco J 9: 343. doi: $10.4172 / 2151-6219.1000343$

Page 6 of 6

8. Soukiazis E, Cerqueira PA, Antunes M (2013) Growth rates constrained by internal and external imbalances and the role of relative prices: empirical evidence from Portugal. Journal of Post Keynesian Economics 36: 275-298.

9. Walter E (2015) Effect of naira devaluation on the Nigeria construction industry. sapient vendors.

10. Medina MU (2015) Devaluation and its impact on Ethiopian Economy. Hacettepe University Graduate School of Social.
11. Central Bank of Nigeria (2016) Annual Report and Statement of Accounts. Abuja: Central Bank of Nigeria.

12. Kenneth J (2016) Devaluation and its effect on the Nigeria economy guardian editorial board

13. Pllaha A (2013) The impact of currency depreciation on Trade balances between Albania and its main Trading partners, Bank of Albania. The "J-curve" effect in bilateral Trade. 